\title{
TWO-STORY HOUSE MOVED ON FLAT CARS
}

\section{By Frank W. Dusey}

The incident to which the caption refers is the moving to Creston from Cromwell of the two-story part of the old Revere House on flat cars, as a house n-o-t wrecked or "knocked down." This building, since located in Creston, was called both Revere House and Creston House. Indeed, somewhere in the memory of the writer there exists a shadowy bit of recollection-whether correct or not - that it bore the name of Creston House twice.

Herein the name Revere House is used principally to avoid possible future misunderstanding with another Creston House which in "ye old time" stood at the northwest corner of Pine and Adams, on the recent site of the Sidney. Then, too, there is a Creston Hotel standing at the north-east corner of Elm and Adams.

The Revere House, as we old-timers recall, was built on the south-east corner of Maple and Union. It was a three-story building in front and the rear portion was the two-story part, which is the subject of this article. There seems to be no exact information as to the size; but as a nestimate (or rather a "guestimate") on the part of the writer, the main (three-story part) was 2024 feet wide by, say 36-40 feet long; the long way facing Union street. The addition-the part brought from Cromwell-was about $24 \times 40$. It was all a frame structure.

The building burned Friday, January 31, 1902. This particular Friday certainly lived up to the day's reputation for unluckiness. Not only did the Revere (called Creston at the time) burn, but the water works went wrong, caused by a break in the main out near Lincoln and Adams. It really was due to this break that the hotel burned, rather than to the actual fire itself. The fire was discovered about five o'clock in the morning. The weather was damp and the wind was almost negligible. The water main gave way about six o'clock, and the last wall fell at eight. This particular information was gleamed from the Advertiser of February 4, 1902. 
There is an error, however, in the report of the $A d$ vertiser. It states that the back part of the building was brought from Cromwell in sections. That it was brought as a whole is a fact gleaned from many sources. The writer knew a farmer named Sam Hutchinson, who lived just across the line in Adams county (n. e. 1/4-1372-32) about whose veracity there is no question. He told me that "they just went right along" up the hill east of Cromwell. "As I re-call," he said, "they had a double-header." But of that I am not sure.

Mrs. Herbert Spencer recalls the incident, and also the fact that a man rode the building in the secondstory. This lady is the mother of the present county auditor, and her husband, together with John Hall, is to be credited with the fact that we have at present the beautiful McKinley park. Mr. Spencer was also one of the noted horsemen of the country, having at one time Hydrogen, a noted son of the famous Allerton of the gay nineties. It should be remembered that in those days that south-west Iowa was almost as noted for horses as the famous blue grass region of Kentucky. Queen Alix of Red Oak was another worth-while product of south-west Iowa before the days of automobiles. Incidentally our curator, Mr. Hamilton, suggests that McKinley park ought to be called Hall and Spencer park. $\mathrm{He}$ is right.

\section{MOVER'S WORD BEST AUTHORITY}

But the greatest proof is the statement of the man who did the moving of the house. It is indeed fortunate that the man is yet alive who did what many people (in fact most all) would regard as an impossible stunt.

On June 4th last the writer, together with Tom Hamilton, started to Afton to get the correct information. Tom also took along a friend of his by the name of Elizabeth Ford. Elizabeth seemed at first to object. She actually used language that no lady should utter in presence of gentlemen. Tom finally promised her a drink of fire-water and redeemed his promise as soon 
as possible. Tom confided to me that "Liz" would not be satisfied with even a mixture of city water and firewater. It had to be all fire-water-real fire-water at that. After the drink, Elizabeth purred along like a contented kitten.

Soon we were visiting with Charles Rogers at Afton. Mr. Rogers told us that he and Henry Nun worked at this particular job for C. T. Hyde who had a contract with S. H. Mallory to move the old Revere House (as we call it) from the corner of Ninth and the street west of Broadway at Cromwell to the tracks, put it on flat cars and take it off again at Creston. This location at Cromwell is the site of the present old homestead of the Sparr family. Mrs. Dr. Barber, daughter of W. M. Sparr, says that her parents told her that the abnormally large well on their property was there because it was dug for the supply of the old hotel. This Mr. Nun was a nephew of "Judge" Nun, a rather noted character of the early history of Union county.

S. H. Mallory was a Chariton man, a railroad contractor, both when the old track was laid back in the 60's and 70's but also when the present track was laid between Murray and Creston. He was also Creston's first banker of any note, and the present First National bank in Creston is the successor of the old First National bank, which was known as Mallory's Bank years after it became the corporation.

\section{MALLORY NEEDED A BUILDING}

According to Mr. Rogers, Mallory brought the building to Creston to serve as Mallory's bank. It was located at or near the north-west corner of Maple and Adams. This is at variance with the memory of others who insist that the building was at once taken over to the south side and used as a hotel. But we must concede that the man who moved it ought to know, and the fact too, that it was moved for Mallory must be taken as confirmatory evidence. 
Mr. Rogers still has some of the tools that were used in that moving and remembers it as a tough job at both ends of the line. He cannot remember the date only as being the fall of the year. As it was about 1870, 1871, it would seem that the "Q" should have some records of the train. But there is none that Mr. Hamilton has been able to locate through correspondence with the railroad officials.

This, however, is not surprising. So far as Mr. Rogers is concerned, it was "all in a day's work." People in those days were not given to detail of keeping notes of happenings, not any too much now, by the way. How many of us can recall our first ride in an automobile, and when it was; our first contact with a radio, etc.?

As for railroad records, it is quite likely no records were kept. They just did the job-that was all. Railroading was done then with system subordinate to sense -perhaps too much so. Indeed as late as forty years ago things were run on a pretty much free and easy way. Passes were common, riding on the engine was against the rules, but no one who really wanted the experience failed to get the ride, if an engine was on the road (and steam up) most any one would move her whether he had a right to or not. I have done it myself. The division superintendent was superintendent with a big "S". He hired, and fired and otherwise did about as he pleased, and got away with it-a striking contrast with the present day when he must ask Chicago for an "A. F. E." to stop a leak in a water tank. I have in mind a tank that must have leaked ten million gallons before the red tape was wound up, and unwound, and wound up again, and the tank was finally replaced with a new one. But the roads made money then.

\section{MOVING RISKS INVOLVED}

Speaking of bringing buildings from Cromwell, it should be recalled that there were no overhead bridges over the track then as now over the new double track. It also should be remembered that there were no air- 
brakes then and the hand operated brake on the cars and the "Johnson Bar" (reverse lever) on the locomotive, were the only means of controlling a train when it took a notion to go wild.

Even as late as 1891 the Kansas City end of the south branch-then under separate management-had two engines not equipped with air brakes and were not allowed to come up into Iowa. Now every engine must be equipped with air and eighty-five percent of the cars must have air in working order.

I noted above that the width of the building was to best of my recollection and belief twenty-four feet. But suppose it to be only twenty feet. Therefore, there was seven and a half feet of hang-over on each side of the flat cars, or I should say "overhang." It sounds better. And, as the building was at least twenty-four feet to the gable, it stands to reason that there was not a regular hurricane blowing from either south or north.

Probably there are not a dozen railroad men (outside of Creston) in all this great U. S. A. that would not say that it would be impossible to move a building as this was moved. On the other hand, then there were probably not a dozen railroad men who could be gotten onto a big engine of a modern type on account of the danger of top-heaviness. Indeed, there was considerable speculation when the "Class H's" first came to the "Q" as to whether they were not dangerously near the limit of top-heaviness. Opinions change.

It may be interesting to note that while the distance from outside to outside of the rails is about five feet, that the present distance of four feet, eight and a half inches between rails originated in 1800 , before the advent of steam engines, when old Dobbin and Nell were the motive power. A man by the name of William Jessop concluded to put flanges on the wheels to hold them on rails, instead of having them run on an angle iron. The distance outside to outside was then five feet, and as the rails were one and three-quarters inch wide, it resulted in our rather anomalous standard guage four 
feet and eight and one-half. Still at that, forty years ago, there were guages varying all the way from $4^{\prime} 8 y^{\prime \prime}$ to $4^{\prime} 9^{\prime \prime}$, all using the same equipment, the big idea being that one engineer had other ideas than his brothers in the play of the wheels within the guage. The "Pennsy" changed from a $4^{\prime} 9^{\prime \prime}$ to the standard in 1892, if I recall correctly.

\section{When Cromwell Moved to Creston}

Now, moving houses on flat cars was a rather commonplace affair in those days for the farm boys to observe between here and Cromwell. Ask Attorney Richard Brown, through whose father's farm the road ran.

These same boys who were so blase about the mere moving of a house on cars, would have gone half way to Des Moines to have seen a Ford car. While the boys -and men too-of today would probably go to Des Moines to see a house moved as was done then. Different times. Different customs.

The "Q" (or rather the "B" and "M") determined to have a division station somewhere in this vicinity. They did not have sense enough-or had too much rather - to try to run an engine all over the continent without being put up for possible repairs in a round house. Now, engines must have water. Camels, and men too, may do without for quite a while, but water, water, and still more water, is the everlasting cry of a locomotive.

Three sites were under consideration, one at the crossing of Tweive Mile (pardon me, “Thompson's Fork”) west of Afton, a location that will be called to mind by saying now the "Poor Farm." Pardon again-the "County Home," or "Union Switch," because there was a switch there in the days of the old single track; also at Creston and Cromwell. These two places were laid out so that the railroad had a right of way before the town. By the way, at Afton, the railroad had to acquire a right of way through laid-out lots, as Afton is a town older than the railroad. 
The site at Creston (that is Creston to be) was passed up in favor of Cromwell on account of the better water supply available. A dam was built near the Adams county line and backed the water up to about the line of Broadway street in Cromwell (the main street of Cromwell today). Among others encouraged to locate in Cromwell was a Mr. Thurlby who had fed and housed the contractor's men since the road left Fairfield. He built the Revere House, or whatever it was called then. And because of the change of the railroad's plans the house was moved to Creston.

The final decision as to whether Cromwell or Creston should be the division station is a matter worthy of note and I hope that Richard Brown (who has gone into the subject quite deeply and who probably knows more about it than any other living person) will give us a story on it some time.

However, one of the red letter days of my life was the day that Mr. Hamilton and myself visited Mr. Rogers in Afton. In the nature of things Mr. Rogers is a very old man and is very near the end of the long, long trail that leads beyond the sunset. I would like to recount the story of his life, as he told it to us-the moving of his parents to Afton, his enlistment in the Civil war at Afton, the seige of Vicksburg, where he was a guard of Grant, his return to Afton, and the long trains of "prairie schooners" that carried the emigrants beyond the Missouri before the railroads.

But, this would better be the subject of another article and also better be written by himself, or by his daughter at his dictation. If she so chooses, the daughter may take this last remark as a hint. But, somebody, somewhere, should see that the tools with which the old Revere was moved are preserved. It shows what real men can do when no "experts" are around. 
Copyright of Annals of Iowa is the property of State of Iowa, by \& through the State Historical Society of Iowa and its content may not be copied or emailed to multiple sites or posted to a listserv without the copyright holder's express written permission. However, users may print, download, or email articles for individual use. 